\title{
Promotion of Extrinsic Apoptosis Pathway in HCT-116 Human Colorectal Cancer Cell Line by Sodium Butyrate as Histone Deacetylase Inhibitor
}

\author{
Ainaz Mashayekhi ${ }^{1}$, Flora Forouzesh ${ }^{2,3,}{ }^{*}$ and Mohammadreza Mashayekhi ${ }^{4}$ \\ 1 MSc Student of Genetics, Department of Genetics, Faculty of Basic Sciences, Tabriz Branch, Islamic Azad University, Tabriz, Iran \\ 2 Assistant Professor, Department of Genetics, Faculty of Advanced Sciences and Technologies, Tehran Medical Sciences, Islamic Azad University, Tehran, Iran \\ ${ }_{3}$ Medical Genomics Research Center, Tehran Medical Sciences, Islamic Azad University, Tehran, Iran \\ ${ }_{4}^{4}$ Assistant Professor, Department of Genetics, Faculty of Basic Sciences, Tabriz Branch, Islamic Azad University, Tabriz, Iran
}

* Corresponding author: Flora Forouzesh, Department of Genetics, Faculty of Advanced Sciences and Technologies, Tehran Medical Sciences, Islamic Azad University, Tehran, Iran. Tel: +982122006660-7; Fax: +982122600714; Email: f8forouzesh@gmail.com, forouzesh@iautmu.ac.ir

Received 2020 November 03; Revised 2020 November 21; Accepted 2020 December 09.

\begin{abstract}
Background: Colorectal cancer (CRC) has already been considered the fourth leading cause of mortality worldwide as the genes involved in apoptotic pathways and alterations of reversible epigenetic have an important role in the progression of CRC.

Objectives: The current study aimed to evaluate the effect of sodium butyrate as a histone deacetylase inhibitor on the alterations of the gene expression of FAS, Fas ligand (FASL), Death receptor 4 (DR4), Death receptor 5 (DR5), and tumor necrosis factor-related apoptosisinducing ligand (TRAIL) in HCT-116 CRC cell line.

Methods: HCT-116 cell line was cultured in Dulbecco's Modified Eagle Medium. The cytotoxicity effect of sodium butyrate on HCT-116 was evaluated using 3-(4, 5-dimethylthiazol-2-yl)-2, 5- diphenyltetrazolium bromide assay for three incubation times (i.e., 24, 48, and 72 h). The half-maximal inhibitory concentration $\left(\mathrm{IC}_{50}\right)$ values were determined. The optimum concentration was within the range of $6.25-$ $200 \mathrm{mM}$. The cellular ribonucleic acid was extracted, and complementary deoxyribonucleic acid was synthesized. Finally, the alterations of the gene expression of FAS, FASL, DR4, DR5, and TRAIL were assessed by real-time polymerase chain reaction (PCR).

Results: The $\mathrm{IC}_{50}$ levels for three incubation times were $50,12.5$, and $6.25 \mathrm{mM}$, respectively. The obtained results of real-time PCR demonstrated a significant increase in the gene expression of TRAIL, DR5, and FAS in comparison to that of the untreated cells as the control group at the three incubation times. The DR4 gene expression significantly increased in comparison to that reported for the control group at 48 and $72 \mathrm{~h}$ of incubation. In addition, FASL gene expression remarkably decreased at the three incubation times.

Conclusion: Sodium butyrate could show cytotoxicity effect on CRC cell lines through the induction of death receptors in the extrinsic apoptotic pathway. The obtained results of this study revealed that the optimum effect of sodium butyrate is an incubation timedependent and concentration-dependent manner.
\end{abstract}

Keywords: Apoptosis, Colorectal cancer, HCT-116, Sodium butyrate

\section{Background}

Colorectal cancer (CRC) is a multifactorial disease and the fourth leading cause of cancer-related mortality in the world (1). Performed studies on various agents involved in the incidence of CRC demonstrated that diet, obesity, body mass index, smoking, aging, and alcohol and excessive meat consumption could have an important role in the development of cancer. The CRC is often observed in individuals over the age of 75 years (2). Recently, the rising incidence of CRC has been reported that could be due to lifestyle, nutrition, and reduction of physical activities (3).

In this regard, apoptosis is a form of programmed cell death occurring in various organs, such as the liver, and spleen, and gastrointestinal system (4). Apoptosis impairment is one of the key mechanisms in cancer occurrence (5). In addition, apoptosis processes consist of two pathways in which releasing cytochrome $\mathrm{C}$ from mitochondria to the cytoplasm is related to intrinsic pathways. On the other hand, some of the molecules, such as FAS, Fas ligand (FASL), tumor necrosis factor-related apoptosis-inducing ligand (TRAIL), Death receptor 4 (DR4), and Death receptor 5 (DR5), have important roles in the extrinsic pathway $(6,7)$. The genes of these molecules are considered tumor inhibitor genes (8).

Apoptosis could be triggered by the engagement of FASL with its specific receptor FAS. The binding of the homotrimer ligand of $F A S$ to $F A S$ leads to the accumulation of the receptors, and the activated receptors recruit the adaptor molecule (i.e., Fasassociated protein with death domain [FADD]) through the interaction with the death domain. The FADD with the recruiting of procaspase- 8 causes to form the death-inducing signaling complex (DISC), a multi-protein complex from death receptors; finally, activated caspase- 8 is separated from the DISC, and caspase-3 leads to death (9).

The FAS is expressed in activated $\mathrm{T}$ cells and lymphoid cells, such as B, T, and natural killer (NK)

Copyright (c) 2021, Author(s). This is an open-access article distributed under the terms of the Creative Commons Attribution-NonCommercial 4.0 International License (http://creativecommons.org/licenses/by-nc/4.0/) which permits copy and redistribute the material just in noncommercial usages, provided the original work is properly cited 
cells. The FAS/FASL cause to induce apoptosis in cancer cells and maintain immune hemostasis (10). The FAS/FASL expression by cancer cells indicates that these cells are resistant to apoptosis through CD95L mediation $(11,12)$. Furthermore, some studies showed that FAS expression is downregulated in CRC cells resulting in resistance to apoptosis.

The TRAIL is another protein acting as a ligand to kill the cells through programmed cell death. This protein can induce apoptosis in many types of tumor cells and deformed cells $(13,14)$. However, the TRAIL gene is expressed in various immune cells, such as $\mathrm{T}$ cells and NK cells, that are capable of preventing the metastasis of tumor cells; nevertheless, it does not have a performance in normal cells. Therefore, it could be a useful option for the treatment of some cancers $(15,16)$.

The TRAIL with binding to two closely related receptors that are DR4 and DR5 facilitates the induction of apoptosis in malignant cells. However, several studies indicated that some tumor cells are resistant to the apoptotic effects of TRAIL. The deleterious mutations arising in DR4 and DR5 can also cause such resistance $(17,18)$. On the other hand, histone deacetylase inhibitors (HDACi) are regarded as novel chemotherapeutic drugs inducing apoptosis via the promotion of two apoptotic pathways and upregulation of DR5 gene expression. Furthermore, HDACi are capable of sensitizing colon cancer cells to TRAIL- and FAS- mediated apoptosis $(19,20)$.

Sodium butyrate $(\mathrm{NaB})$ is a short-chain saturated fatty acid existing in the human intestinal wall as a food metabolite. $\mathrm{NaB}$ could exhibit an anticancer effect as an HDACi, and several studies indicated that $\mathrm{NaB}$ is a general inducer of growth arrest and apoptosis in colon cancer cell lines (21). Nonetheless, $\mathrm{NaB}$ is an effective metabolite in gene expression, transcription activators, and histone acetylation in cancer cells, with little effect on normal cells (22). According to the above-mentioned findings, $\mathrm{NaB}$ is considered a drug for the elimination of tumor cells through activating apoptosis mechanisms (23). In addition, the utilization of HDACi in cancer treatment has led to obtaining beneficial results in recent years.

\section{Objectives}

One of the most primary goals of drug design in cancer therapy is the effect on the vital mechanisms of cancerous cells. Apoptosis is the most important biological mechanism with a critical role in the balance between the expressions of genes involved in the cell hemostasis. The achievement of the molecular effects of drugs on cells is very important because they exert various effects on different types of cancers which have multiple effects on gene expression. Moreover, the effect varies according to the response rate to the drug leading to different gene expressions. Therefore, the present study aimed to evaluate the effect of $\mathrm{NaB}$ on extrinsic apoptosis pathways genes, FAS receptor, and TRAIL receptor simultaneously in colorectal carcinoma HCT-116 cells.

\section{Methods}

\subsection{Cell culture}

As the human CRC cell line, HTC-116 was used and prepared by Pasteur Institute of Iran. The HTC116 cell lines were cultured in Dulbecco's Modified Eagle Medium (Gibco, US) with 10\% fetal bovine serum (Gibco, US) and antibiotics, including streptomycin $(100 \mu \mathrm{g} / \mathrm{ml})$ and penicillin $(1,000$ units $/ \mathrm{ml}^{-1}$ ). They were incubated in a $5 \% \quad \mathrm{CO}_{2}$ humidified incubator at $37^{\circ} \mathrm{C}$. When the confluency of the cells reached $80 \%$, trypsin (25\%; Gibco, US) and ethylenediaminetetraacetic acid (0.02\%; Gibco, US) were used for the separation of the cells.

\subsection{Sodium butyrate treatment}

Sodium butyrate was dissolved in sterile water. The harvested cells were seeded into 96-well plates. The different concentrations of $\mathrm{NaB}$ (i.e., 6.25, 12.5, 25, $50,100,150$, and $200 \mathrm{mM}$ ) were used for the treatment of the cells. They were incubated in a $5 \%$ $\mathrm{CO}_{2}$ humidified incubator at $37^{\circ} \mathrm{C}$. After 24,48 , and 72 $\mathrm{h}$ of incubation, the cell viability was evaluated using 3-(4, 5-dimethylthiazol-2-yl)-2, 5- diphenyltetrazolium bromide (MTT) assay.

\subsection{MTT Assay}

The MTT assay was used to evaluate the effect of $\mathrm{NaB}$ on cell proliferation, and the half-maximal inhibitory concentration ( $\mathrm{IC}_{50}$ ) values were also calculated. Briefly, the density values of 80,000 , 50,000 , and 20,000 cells/well were plated onto 96well plates (Sigma-Aldrich, US) and treated with different concentrations of $\mathrm{NaB}$ (range: 6.25 -200 $\mathrm{mM}$ ) and incubated for 24,48 , and $72 \mathrm{~h}$. The untreated cells were used as the control group. Then, $100 \mu \mathrm{l}$ of MTT solution $(0.5 \mathrm{mg} / \mathrm{ml})$ was added to each well and incubated at $37^{\circ} \mathrm{C}$ with $5 \% \mathrm{CO}_{2}$ for $3 \mathrm{~h}$. Subsequently, $50 \mu$ l of dimethyl sulfoxide solution was dispensed to each well, and the plate was gently shacked. Finally, an enzyme-linked immunosorbent assay reader was applied for the measurement of optical density (OD) at a wavelength of 546/630. Cell viability percentage was calculated using the following formula:

$(\%)=($ ODexp $) /($ ODcon $) * 100$

Where ODexp and ODcon stand for the ODs of the treated and untreated cells, respectively.

\subsection{RNA extraction and quantitative real-time PCR \\ Total cellular ribonucleic acid (RNA) was extracted from both groups, including the group treated with $\mathrm{NaB}$ and the control group (i.e.,}


untreated cells), using RNX reagent (Sinaclon, Iran) according to the manufacturer' instructions. The quality of the extracted RNA was evaluated by agarose electrophoresis gel. In addition, $2000 \mathrm{ng}$ of RNA was reverse-transcribed to complementary deoxyribonucleic acid (cDNA). The cDNA was synthesized using a cDNA synthesis kit (YektaTajhiz, Iran) according to the manufacturer's instruction. The TRAIL, DR4, DR5, CD95, and CD95L messenger RNA (mRNA) levels were determined by quantitative real-time PCR. Glyceraldehyde 3phosphate dehydrogenase (GAPDH) primer was used as an internal control. All the experiments were performed in duplicate. Specific primers were designed that are brought as follows:

GAPDH forward (F): 5'-

GAAGGTGAAGGTCGGAGTC-3', reverse (R): 3'-

GAAGATGGTGATGGGATTTC-5'

CD95 forward (F): 5'-

TGCCAAGAAGGGAAGGAGAA-3', reverse (R): 3'-

CGGGTGCAGTTTATTTCCAC-5'

$C D 95 L$ forward (F): 5'-

AGCAAATAGGCCACCCCAGTCC-3', reverse (R): 5' TGGCTCAGGGGCAGGTTGTTG-3'.

DR4 forward (F): 5'- TCCAGCAAATGGTGCTGAC-3', reverse (R): 3'-GAGTCAAAGGGCACGATGTT-5'

DR5 forward (F): 5'-CCAGCAAATGAAGGTGATCC3', reverse (R): 3'-GCACCAAGTCTGCAAAGTCA-5'

TRAIL forward (F): 5'-GAAGGTGAAGGTCGGAGTC3', reverse (R): 5'-GACCAGTTCACCATTCCTC-3'
Real-time PCR was carried out with the conditions of $95^{\circ} \mathrm{C}$ for $180 \mathrm{sec}, 40$ cycles of $5 \mathrm{sec}$ at $95^{\circ} \mathrm{C}$ and 30 sec at $60^{\circ} \mathrm{C}, 95^{\circ} \mathrm{C}$ for $30 \mathrm{sec}$, and $55^{\circ} \mathrm{C}$ for $30 \mathrm{sec}$. Melting curve analysis was used to verify the single PCR product amplification of each primer.

\subsection{Statistical analysis}

The obtained results were presented as the mean standard error of the mean. One-way analysis of variance statistical method was utilized to analyze the data. Statistical analysis was also carried out using Graph Pad Prism software (version 6). Regression analysis was used for the calculation of IC 50 values. A pvalue of less than 0.05 was considered statistically significant. Relative expression software tool 2009 (REST 2009) software was utilized to analyze target gene expression.

\section{Results}

\subsection{Cytotoxicity assay}

In the present study, 80000, 50000, and 20000 HCT-116 cells were seeded into 96 -well plates for 24 , 48, and $72 \mathrm{~h}$ (unpublished), respectively, and treated with different concentrations of $\mathrm{NaB}$ (range: 6.25-200 $\mathrm{mM}$ ). The cytotoxicity effect was evaluated by the MTT assay. The cell growth rate was inhibited in a dose-dependent manner. The $\mathrm{IC}_{50}$ values of $\mathrm{NaB}$ on HCT-116 cells were determined (figures $1 \mathrm{~A}, 1 \mathrm{~B}$, and 1C). The $\mathrm{IC}_{50}$ value after $24 \mathrm{~h}$ of incubation was
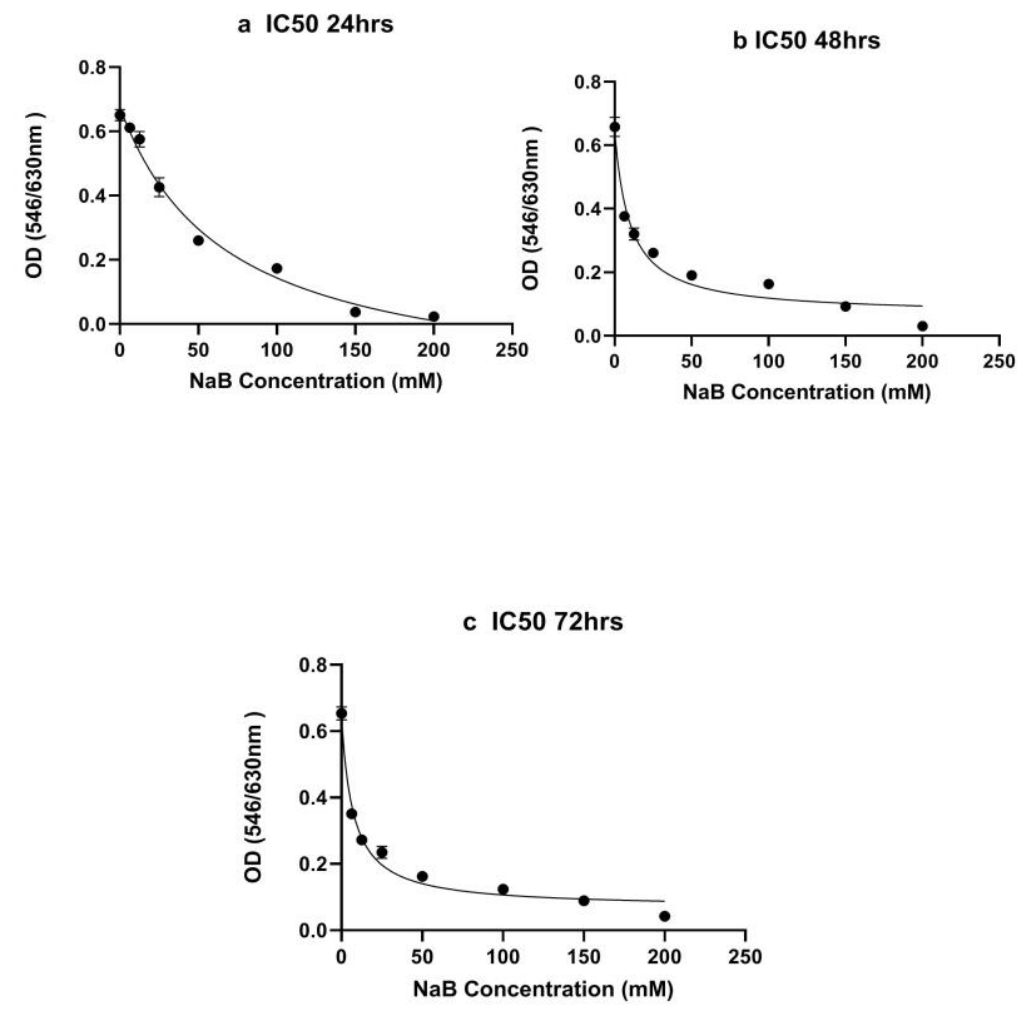

Figure 1. Cytotoxic effect of NaB on HCT-116 cells measured by 3-(4, 5-dimethylthiazol-2-yl)-2, 5- diphenyltetrazolium bromide assay; half-maximal inhibitory concentration values at 24,48 , and $72 \mathrm{~h}$ reported as $50,12.5$, and $6.25 \mathrm{mM}$, respectively 
reported as $50 \mathrm{mM}$. The $\mathrm{IC}_{50}$ concentration after $48 \mathrm{~h}$ of incubation was less than $12.5 \mathrm{mM}$ (within the range of $6.25-12.5 \mathrm{mM}$ ), and the $\mathrm{IC}_{50}$ concentration after $72 \mathrm{~h}$ of incubation was almost $6.25 \mathrm{mM}$. The confidence interval was reported as $95 \%$.

\subsection{Gene expression}

The effect of $\mathrm{NaB}$ on the mRNA levels of FAS, FasL, $D R 4, D R 5$, and TRAIL was statistically significant.

\subsubsection{FASL MRNA expression}

HCT-116 cells were incubated with $\mathrm{IC}_{50}$ concentration of $\mathrm{NaB}$ and concentration after and before $\mathrm{IC}_{50}$ concentrations (i.e., 25, 50, and $100 \mathrm{mM}$ for $24 \mathrm{~h}$ of incubation; $6.25,12.5$, and $25 \mathrm{mM}$ for 48 and $72 \mathrm{~h}$ of incubation). After $24 \mathrm{~h}$ of treatment with $\mathrm{NaB}$, the mRNA level of FASL significantly reduced about 21 and 9.84 folds at 25 and $50 \mathrm{mM}$ concentrations, respectively, compared to that reported for the untreated group $(\mathrm{p}<0.05$, Figure 2A). After $48 \mathrm{~h}$ of treatment with $\mathrm{NaB}, F A S L$ expression significantly decreased about 14.77 and 12.38 folds at concentrations of 12.5 and $6.25 \mathrm{mM}$, respectively, compared to that of the untreated group ( $\mathrm{P}<0.05$; Figure $2 \mathrm{~B})$. After $72 \mathrm{~h}$ of treatment with $\mathrm{NaB}$, the gene expression of FASL significantly reduced about 1.86, 16.33, and 30.27 folds at concentrations of $6.25,12.5$, and $25 \mathrm{mM}$, compared a $24 \mathrm{hrs}$

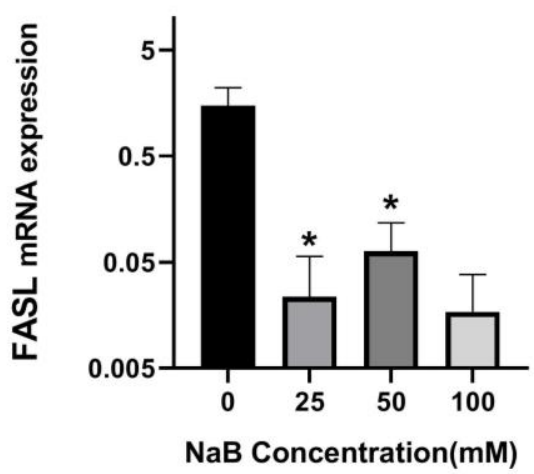

b $48 \mathrm{hrs}$

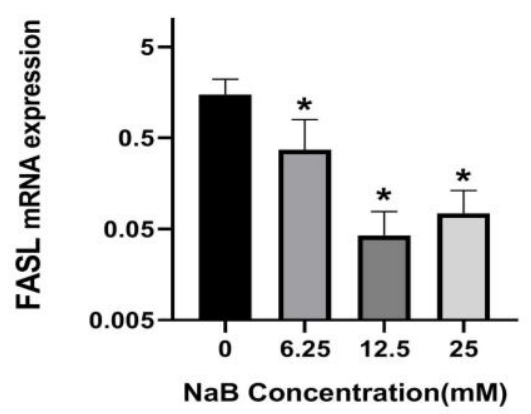

\section{c $72 \mathrm{hrs}$}

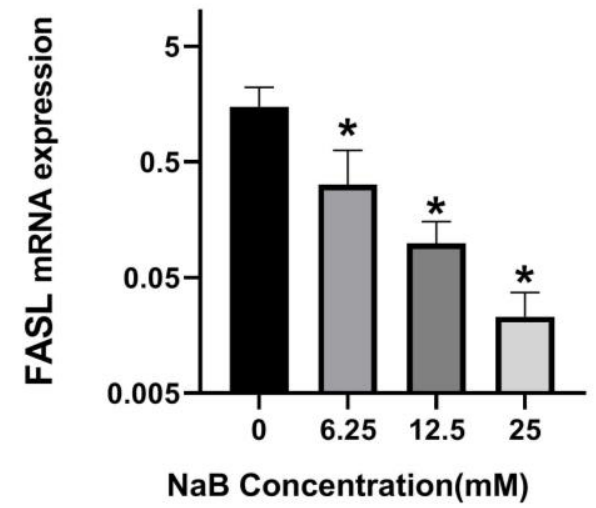

Figure 2. Fas ligand (FASL) gene expression; A) messenger cellular ribonucleic acid level of $F A S L$ after $24 \mathrm{~h}$ of treatment with NaB showing a significant reduction at concentrations of 25 and $50 \mathrm{mM}$; B), remarkable reduction of gene expression of $F A S L$ at concentrations of 6.25 and $12.2 \mathrm{mM}$ after $48 \mathrm{~h}$ of treatment with $\mathrm{NaB}$; C) significant reduction at concentrations of $6.25,12.5$, and $25 \mathrm{mM}$ after $72 \mathrm{~h}$ of treatment with $\mathrm{NaB}$; evaluation of $F A S L$ gene expression using quantitative real-time polymerase chain reaction; ${ }^{*} \mathrm{P}<0.05$ 
to that reported for the untreated group $(\mathrm{P}<0.05$; Figure 2C). The obtained results showed a time- and dose-dependent downregulation in the mRNA level of the FASL gene.

\subsubsection{FAS mRNA expression}

NaB-treated HCT-116 cells were incubated with IC 50 concentrations (i.e., 25, 50, and $100 \mathrm{mM}$ for $24 \mathrm{~h}$ of incubation; $6.25,12.5$, and $25 \mathrm{mM}$ for 48 and $72 \mathrm{~h}$ of incubation). There was a significant increase in 2.31 and 1.12 folds at concentrations of 50 and 100 $\mathrm{mM}$ in the treated group with $\mathrm{NaB}$, compared to that reported for the control group after $24 \mathrm{~h}$ of incubation $(\mathrm{P}=0.005$; Figure $3 \mathrm{~A})$. However, a concentration of $25 \mathrm{mM}$ caused a 1.33-fold remarkable reduction in comparison to that of the control group $(\mathrm{P}=0.001)$. After $48 \mathrm{~h}$ of treatment with $\mathrm{NaB}$, the mRNA level of FAS significantly increased $6.23,3.021$, and 7.38 folds, compared to that reported for the control group $(\mathrm{P}=0.001$; Figure $3 \mathrm{~B})$. In addition, the results after $72 \mathrm{~h}$ of treatment with $\mathrm{NaB}$ showed a significant increase of 10.41 and 4.79 folds, compared to that of the control group at concentrations of 6.25 and $12.5 \mathrm{mM}(\mathrm{P}=0.005$; Figure 3C).

\subsubsection{DR4 gene expression}

NaB-treated HCT-116 cells were incubated with a $24 \mathrm{hrs}$

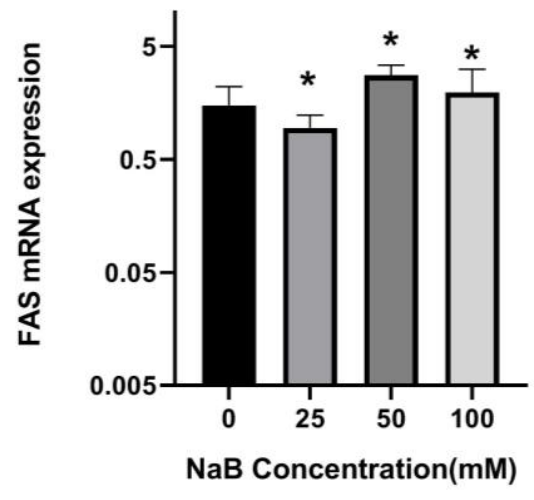

b $48 \mathrm{hrs}$

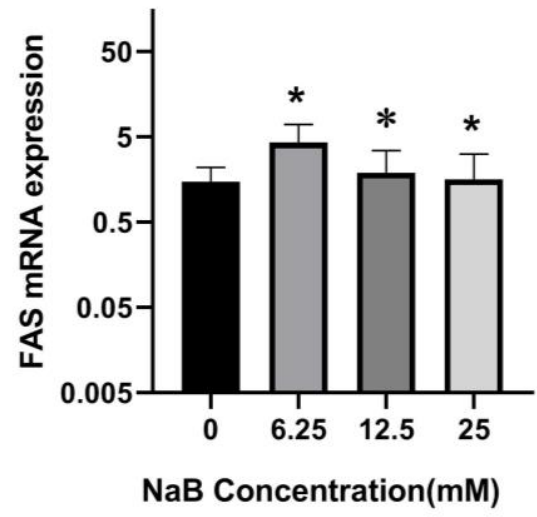

c $72 \mathrm{hrs}$

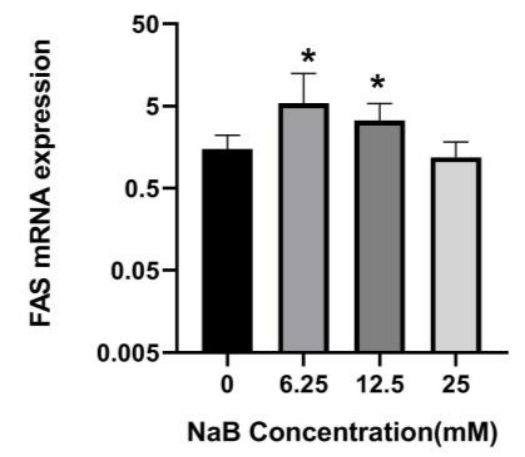

Figure 3. FAS gene expression; A), significant increase of FAS gene expression at concentrations of 50 and $100 \mathrm{mM}$ after $24 \mathrm{~h}$ of treatment with $\mathrm{NaB}$, compared to that reported for the untreated group; B) significant increase at concentrations of $6.25,12.5$, and 25 $\mathrm{mM}$ caused by FAS gene expression after $48 \mathrm{~h}$ of treatment with $\mathrm{NaB}$, compared to that reported the untreated group; C) FAS gene expression after $72 \mathrm{~h}$ of treatment with $\mathrm{NaB}$ demonstrating a significant upregulation at concentrations of 6.25 and $12.5 \mathrm{Mm}$, compared to that reported for the untreated control group; evaluation of FAS gene expression using quantitative real-time polymerase chain reaction; ${ }^{*} \mathrm{P}<0.05$ 
$\mathrm{IC}_{50}$ concentrations (i.e., 25, 50, and $100 \mathrm{mM}$ for $24 \mathrm{~h}$ of incubation; $6.25,12.5$, and $25 \mathrm{mM}$ for 48 and $72 \mathrm{~h}$ of incubation). The results obtained from the DR4 gene expression demonstrated a 5.83-fold remarkable reduction at a concentration of $25 \mathrm{mM}$, compared to that reported for the control group after $24 \mathrm{~h}$ of treatment with $\mathrm{NaB}(\mathrm{P}=0.005$; Figure $4 \mathrm{~A})$. At concentrations of 50 and $100 \mathrm{mM}$, there was a reduction in DR4 gene expression. However, this reduction was not remarkable in comparison to that of the control group. After $48 \mathrm{~h}$ of treatment with $\mathrm{NaB}$, DR4 gene expression showed a 21.85- and 88.95-fold significant increase at concentrations of 6.25 and $25 \mathrm{mM}$ respectively, compared to that reported for the control group $(\mathrm{P}=0.005$; Figure 4B). Furthermore, there was a 69.79-fold significant increase at a concentration of $6.25 \mathrm{mM}$ in comparison to that of the control group after $72 \mathrm{~h}$ of treatment with $\mathrm{NaB}(\mathrm{P}=0.005$; Figure 4C).

\subsubsection{DR5 gene expression}

NaB-treated HCT-116 cells were incubated with IC 50 concentrations of 25,50 , and $100 \mathrm{mM}$ for $24 \mathrm{~h}$ of incubation in addition to $6.25,12.5$, and $25 \mathrm{mM}$ for 48 and $72 \mathrm{~h}$ of incubation. The results of the DR5 gene expression showed that 1.67-, 1.81-, and 1.59-fold significant increases were observed at concentrations of 25,50 , and $100 \mathrm{mM}$, respectively, compared to those reported for the control group after $24 \mathrm{~h}$ $(\mathrm{P}=0.005$; Figure $5 \mathrm{~A})$. The mRNA level of the DR5 gene remarkably increased about 6.86 and 74 folds at concentrations of 6.25 and $25 \mathrm{mM}$, respectively, compared to that of the control group after $48 \mathrm{~h}$ of incubation $(\mathrm{P}=0.005)$. Nevertheless, at a concentration of $12.5 \mathrm{mM}$, there was a significant decrease of about 3.08 folds in DR5 gene expression in comparison to that of the control group after $48 \mathrm{~h}$ of treatment with $\mathrm{NaB} \quad(\mathrm{P}=0.005$; Figure 5B). Additionally, DR5 gene expression in NaB-treated

\section{a $24 \mathrm{hrs}$}

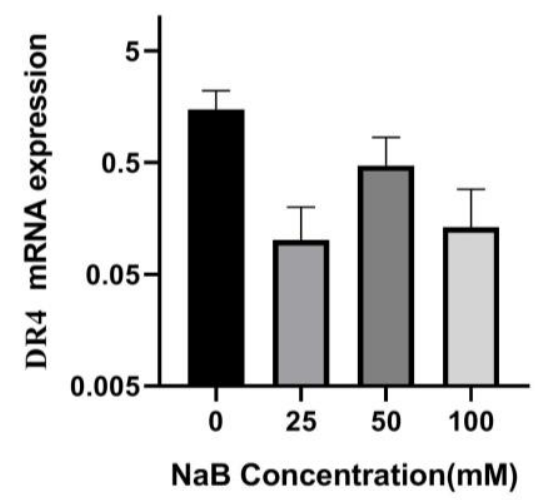

b $48 \mathrm{hrs}$

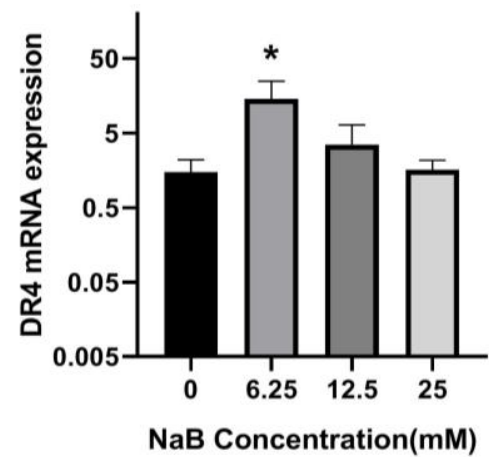

c: $72 \mathrm{hrs}$

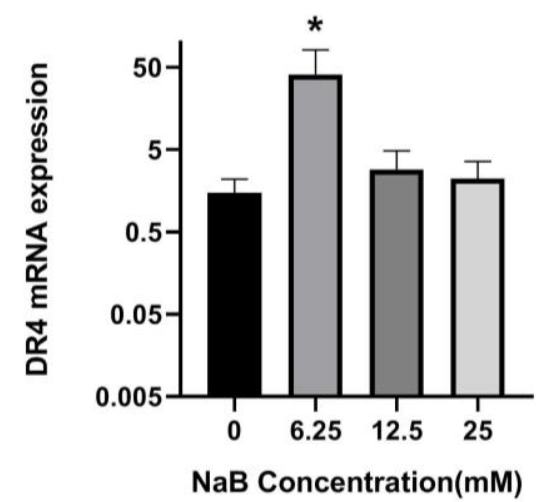

Figure 4. Death receptor 4 (DR4) gene expression; A) significant reduction of $D R 4$ gene expression at concentration of $25 \mathrm{mM}$ after $24 \mathrm{~h}$ of treatment with $\mathrm{NaB}$; B) DR4 gene expression after $48 \mathrm{~h}$ of treatment with $\mathrm{NaB}$ showing significant increase at concentrations of 6.25 and $25 \mathrm{mM}$, compared to that reported for the control group; C) DR4 gene expression demonstrating significant increase at concentration of $6.25 \mathrm{mM}$ after $72 \mathrm{~h}$ of treatment with $\mathrm{NaB}$, compared to that reported for the control group; evaluation of $D R 4$ gene expression using quantitative real-time polymerase chain reaction; ${ }^{*} \mathrm{P}<0.05$ 
a: $24 \mathrm{hrs}$

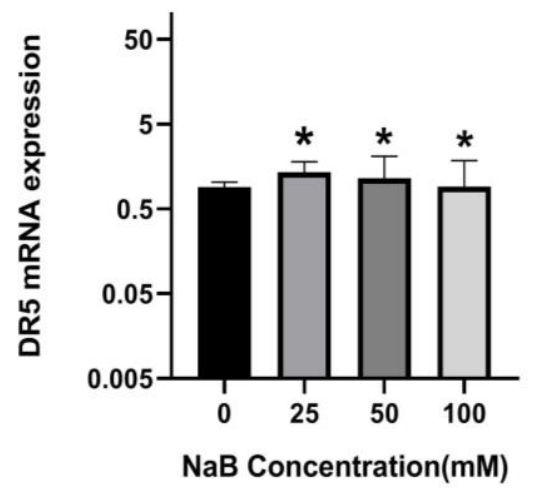

b: 48 hrs

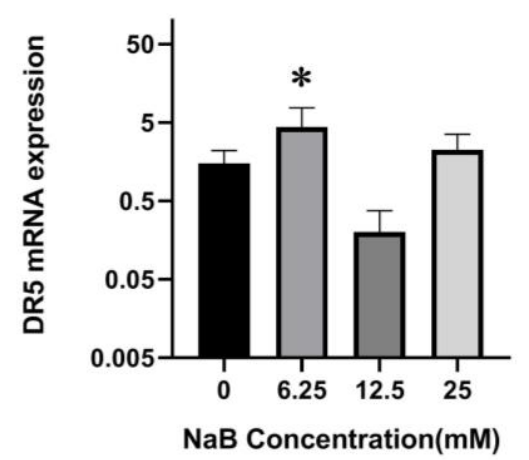

c : $72 \mathrm{hrs}$

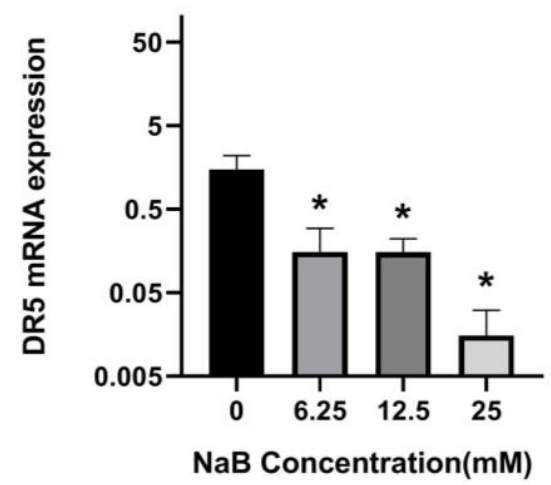

Figure 5. Death receptor 5 (DR5) gene expression; A) DR5 gene expression after 24 h of treatment with NaB showing a significant increase at three concentrations of 25,50 , and $100 \mathrm{mM}$, compared to that reported for the control group; B) $D R 5$ gene expression after 48 $\mathrm{h}$ of treatment with $\mathrm{NaB}$ causing significant increase at concentrations of 6.25 and $25 \mathrm{mM}$; significant reduction at concentration of 12.5 $\mathrm{mM}$ in NaB-treated HCT-116 cells, compared to that reported for the untreated control group; C) significant reduction of DR5 gene expression at concentrations of $6.25,12.5$, and $25 \mathrm{mM}$ after $72 \mathrm{~h}$ of treatment with NaB; evaluation of $D R 5$ gene expression using quantitative real-time polymerase chain reaction; ${ }^{*} \mathrm{P}<0.05$

HCT-116 cells showed significant reductions of about $3.23,4.07$, and 2.92 folds at concentrations of 6.25 , 12.5 , and $25 \mathrm{mM}$, respectively, compared to those reported for the control group after $72 \mathrm{~h}$ of incubation $(\mathrm{P}=0.001$; Figure $5 \mathrm{C})$.

\subsubsection{TRAIL gene expression}

NaB-treated HCT-116 cells were incubated with IC 50 concentrations of 25,50 , and $100 \mathrm{mM}$ for $24 \mathrm{~h}$ of incubation in addition to $6.25,12.5$, and $25 \mathrm{mM}$ for 48 and $72 \mathrm{~h}$ of incubation. After $24 \mathrm{~h}$ of treatment with $\mathrm{NaB}$, the mRNA level of TRAIL significantly increased about 2.66, 17.87, and 5.18 $\mathrm{mM}$ folds at concentrations of $25,12.5$, and $25 \mathrm{mM}$, respectively, compared to that of the control group $(\mathrm{P}=0.005$; Figure 6A). Furthermore, after $48 \mathrm{~h}$ of treatment with $\mathrm{NaB}$, TRAIL gene expression remarkably increased at concentrations of 6.25 and $25 \mathrm{mM}$, respectively, compared to that reported for the untreated group $(\mathrm{P}<0.05 ; \mathrm{P}=0.005$; Figure $6 \mathrm{~B})$. The results obtained from the NaB treated HCT-116 cells demonstrated significant increases of about 4.33 and 4.45 folds at concentrations of 6.25 and $25 \mathrm{mM}$, compared to those of the control group after $72 \mathrm{~h}$ of incubation $(\mathrm{P}=0.005$; Figure 6C).

\section{Discussion}

The CRC was caused by the excessive growth of abnormal colon cells in the part of the rectum or colon. Moreover, the apoptosis process removes damaged cells, and the hallmark index of cancer cells evade programmed cell death. The extrinsic pathway of apoptosis is usually triggered by binding FASL to CD95 on the surface of the cell membrane. The lacking balance between cell growth and apoptosis is one of the important mechanisms for the induction of CRC $(2,24,25)$. In addition, hyperacetylation is the mechanism through which the tumor cells disrupt gene expression. The gene expression of histone deacetylase increases in CRC performing toward the deacetylation of target gene expression. The HDACi 
a: $24 \mathrm{hrs}$

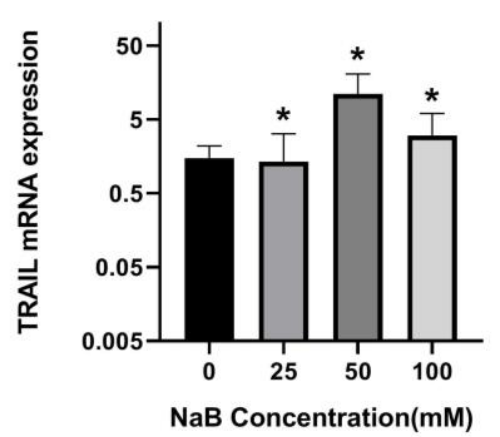

b: 48 hrs

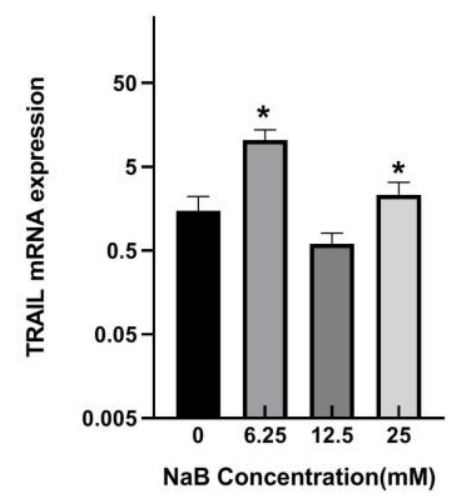

c: $72 \mathrm{hrs}$

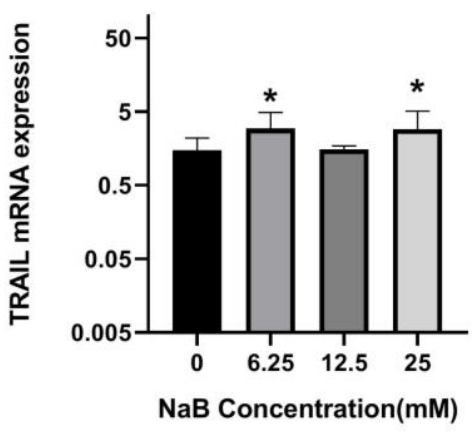

Figure 6. Tumor necrosis factor-related apoptosis-inducing ligand (TRAIL) gene expression; A) up regulation of TRAIL gene expression at concentrations of 25,50 , and $100 \mathrm{mM}$ after $24 \mathrm{~h}$ of treatment with $\mathrm{NaB}$; B) increase of TRAIL gene expression at concentrations of 6.25 and $25 \mathrm{mM}$ after $48 \mathrm{~h}$ of treatment with $\mathrm{NaB}$ in NaB-treated HCT-116 cells, compared to that reported for the untreated group; C) significant increase of TRAIL gene expression at concentrations of 6.25 and $25 \mathrm{mM}$ after $72 \mathrm{~h}$ of treatment with $\mathrm{NaB}$, compared to that reported for the untreated control group; evaluation of TRAIL gene expression using quantitative real-time polymerase chain reaction; $* \mathrm{P}<0.05$

can induce apoptosis in tumor cells with the regulation of apoptotic gene expression via extrinsic and intrinsic pathways (26).

The effect of $\mathrm{NaB}$ as an HDACi on gene expression in cancer cells has been indicated in several studies $(27,28)$. Owing to the important characteristic of sodium butyrate, it could be a reliable adoption for the assessment of its role in apoptotic gene expression. In the present study, the optimum concentration of sodium butyrate was evaluated on gene expression involved in extrinsic apoptosis pathways, including TRAIL, DR4, DR5, $C D 95$, and $C D 95 L$. The obtained results of the MTT assay showed that $\mathrm{IC}_{50}$ values were $50,6.25-12.5$, and $6.25 \mathrm{mM}$ for 24,48 , and $72 \mathrm{~h}$ of treatment, respectively.

Yamamura et al. have studied the effect of $\mathrm{NaB}$ at concentrations of 1 and $5 \mathrm{mM}$ for 24 and $48 \mathrm{~h}$ of treatment, respectively. They indicated that $\mathrm{NaB}$ is capable of increasing apoptosis at certain concentrations in HCT and SW480 cell lines (29). In the current study, FAS gene expression significantly increased at determined $\mathrm{IC}_{50}$ in 24,48 , and $72 \mathrm{~h}$ of treatment resulting in a considerable increase in apoptosis induction. Furthermore, FASL gene expression reduced at 24, 48, and $72 \mathrm{~h}$ in the aforementioned concentrations. According to previous studies, FASL increased in tumor cells; therefore, its gene expression reduced when treated with certain concentrations of $\mathrm{NaB}$ in three incubation times.

The obtained results of the present study are in line with the findings of other studies carried out on other cancer cell lines. A study conducted by Bernard $\mathrm{B}$ et al. evaluated the effect of $\mathrm{NaB}$ on apoptosis induction with $4 \mathrm{mM}$ of $\mathrm{NaB}$ in $24 \mathrm{~h}$, and the results indicated that induction of $F A S$-mediated apoptosis would increase when treated with $\mathrm{NaB}$ at the specific concentration (30).

Another study was performed on the FAS gene expression in the MCF-7 cell line undergoing the treatment of $2.5-\mathrm{mM} \mathrm{NaB}$ in $48 \mathrm{~h}$ of treatment. It was observed that FAS gene expression was elevated by the treatment with $\mathrm{NaB}$ (31). In addition, the obtained results of the present study from TRAIL gene expression showed a significant increase in the 
three times of incubation, especially at $25 \mathrm{mM}$ that was a common concentration among the treatment times.

Moreover, DR4 gene expression significantly increased at concentrations of 6.25 and $25 \mathrm{mM}$ for 48 $\mathrm{h}$ and only at a concentration of $6.25 \mathrm{mM}$ for $72 \mathrm{~h}$ of treatment with $\mathrm{NaB}$. The DR5 gene expression also significantly increased after $24 \mathrm{~h}$ of treatment at concentrations of 25,50 , and $100 \mathrm{mM}$ and at concentrations of 6.25 and $25 \mathrm{mM}$ for $48 \mathrm{~h}$ of treatment. Hernandez et al. have observed a significant increase in TRAIL gene expression when the KM12C, KML4A, and KM20 cancer cell lines (i.e., colon cancer cells of different metastatic potential) were treated with $\mathrm{NaB}$ after 24 and $48 \mathrm{~h}$ of incubation (32). Furthermore, in another study conducted by Kim et al., $\mathrm{NaB}$ could not show a significant effect on DR4 gene expression. However, there was a significant increase in DR4 gene expression based on the obtained results of the present study (33).

Kim et al. in another study have evaluated the effect of $\mathrm{NaB}$ on TRAIL and their specific receptors that are DR4 and DR5 in the HT-29 cancer cell line. Their results showed that TRAIL-mediated apoptosis increased at a concentration of $4 \mathrm{mM}$ for $24 \mathrm{~h}$ of treatment, and the elevation of DR5 gene expression was observed using the western blot and real-time PCR despite the DR4 gene expression not showing a clear difference. Therefore, Kim et al. observed that $\mathrm{NaB}$ could alter the gene expression with an effect on transcription factor SP1 (29). In the present study, TRAIL gene expression remarkably increased at three studied concentrations after $24 \mathrm{~h}$ and at concentrations of 6.25 and $25 \mathrm{mM}$ after $48 \mathrm{~h}$ of incubation. Moreover, concentrations of 6.25 and 25 $\mathrm{mM}$ demonstrated a significant increase after $72 \mathrm{~h}$ of incubation.

The results of the present study indicated that the expression of FAS, TRAIL, DR4, and DR5 were upregulated, and the expression of CD95L was downregulated. These findings are supported by the experiments showing the enhancement of FAS, TRAIL, $D R 4$, and DR5 and reduction of CD95L in CRC cells. Moreover, abnormal proliferation and excessive growth of cancer cells would occur by a defect in apoptosis accompanied by the deregulation of the cell cycle. As a result, $\mathrm{NaB}$ as an HDACi could promote apoptosis induction. On the other hand, counteracting the innate immune cells against tumors has been indicated.

Plasmacytoid dendritic cells express TRAIL and induce cytotoxicity $\mathrm{T}$ cells (CTLs) to kill the tumor cells. In addition, NK cells could exert cytotoxicity effects on cancer cells through the interaction of FAS/FASL and TRAIL signaling pathways. The FASL and TRAIL were expressed in adaptive immune cells, such as T cells and CTLs, which have cytotoxicity activities against tumor cells. Furthermore,
FAS/FASL expression by cancer cells represents that these cells are resistant to $F A S$-mediated apoptosis. The most common mechanism utilized to evade apoptosis is the regulation of receptor surface expression $(31,32)$.

The FAS expression was downregulated in CRC that could lead to apoptosis resistance; therefore, tumor growth of colorectal carcinoma increases (30). It seems that $\mathrm{NaB}$ may have an effective role in the induction of the apoptosis process in CRC via the reduction of FASL gene expression and increase of TRAIL, DR4, DR5, and FAS gene expression, along with reinforcement of innate and adaptive immune responses, resulting in the facilitation of the apoptosis process.

\section{Conclusion}

Sodium butyrate as an HDACi could affect the gene expression of the extrinsic apoptotic pathway and stimulate apoptosis induction in a treated HTC116 cell line. Overall, the findings of the current study indicated that sodium butyrate has the maximum effect on the optimum concentrations and certain treatment times in CRC. Consequently, the cytotoxicity effect of sodium butyrate is a treatment time-dependent and concentrationdependent manner.

\section{Acknowledgments}

This study was extracted from an MSc thesis by Ainaz Mashayekhi. All the authors would like to express their gratitude to all the individuals involved in this study, especially Medical Genomics Research Center, Tehran Medical Sciences, Islamic Azad University, Tehran, Iran.

\section{Footnotes}

Authors' Contribution: F.F. participated in study design. F.F., A.M., and M.M. participated in data collection, evaluation, and drafting. F.F. and A.M. participated in reverse transcriptase quantitative polymerase chain reaction and statistical analyses. F.F. and A.M. performed sample collection, prepared laboratory working, and conducted molecular experiments. F.F. and A.M. extensively contributed to interpreting the data and drawing conclusions. All the authors edited the final version of this paper for submission, participated in the finalization of the manuscript, and approved the final draft.

Conflict of Interests: The authors declare that there is no conflict of interest.

Ethical Approval: Not applicable.

Funding/Support: No funding was received for conducting this study.

Informed consent: Not applicable. 


\section{References}

1. Wild CP, Stewart BW. World cancer report 2014: World Health Organization; 2014.

2. Boyle P, Leon ME. Epidemiology of colorectal cancer. $\mathrm{Br}$ Med Bull. 2002;64:1-25. doi: 10.1093/bmb/64.1.1. [PubMed: 12421722].

3. Rafiemanesh H, Pakzad R, Abedi M, Kor Y, Moludi J, Towhidi F, et al. Colorectal cancer in Iran: Epidemiology and morphology trends. EXCLIJ. 2016;15:738-44. doi: 10.17179/excli2016-346. [PubMed: 28337105].

4. Elmore S. Apoptosis: a review of programmed cell death. Toxicol Pathol. 2007;35(4):495-516. doi: 10.1080/01926230701320337. [PubMed: 17562483].

5. Johnstone RW, Ruefli AA, Lowe SW. Apoptosis: a link between cancer genetics and chemotherapy. Cell. 2002;108(2):153-64. doi: 10.1016/s0092-8674(02)00625-6. [PubMed: 11832206].

6. Fesik SW, Shi Y. Controlling the caspases. Science. 2001;294(5546):1477-8. doi: 10.1126/science.1062236.

7. Raff M, Alberts B, Lewis J, Johnson A, Roberts K. Molecular Biology of the Cell 4th edition. National Center for Biotechnology InformationÕs Bookshelf; 2002.

8. Green DR. Apoptosis: physiology and pathology: Cambridge University Press; 2011.

9. Rodriguez I, Matsuura K, Khatib K, Reed JC, Nagata S, Vassalli P. A BCL-2 transgene expressed in hepatocytes protects mice from fulminant liver destruction but not rapid death induced by anti-Fas antibody injection. J Exp Med. 1996;183(3):1031-6. doi: 10.1084/jem.183.3.1031. [PubMed: 8642244].

10. Bellgrau D, Gold D, Selawry H, Moore J, Franzusoff A, Duke RC. A role for CD95 ligand in preventing graft rejection. Nature. 1995;377(6550):630-2. doi: 10.1038/377630a0. [PubMed: 7566174].

11. Ivanov VN, Bergami PL, Maulit G, Sato TA, Sassoon D, Ronai Ze. FAP-1 association with Fas (Apo-1) inhibits Fas expression on the cell surface. Mol Cellular Biol. 2003;23(10):3623-35. doi: 10.1128/mcb.23.10.3623-3635.2003. [PubMed: 12724420].

12. Ivanov VN, Ronai Ze, Hei TK. Opposite roles of FAP-1 and dynamin in the regulation of Fas (CD95) translocation to the cell surface and susceptibility to Fas ligand-mediated apoptosis. J Biol Chem. 2006;281(3):1840-52. doi: 10.1074/jbc.M509866200. [PubMed: 16306044].

13. Pitti RM, Marsters SA, Ruppert S, Donahue CJ, Moore A, Ashkenazi A. Induction of apoptosis by Apo-2 ligand, a new member of the tumor necrosis factor cytokine family. J Biol Chem. 1996;271(22):12687-90. doi: 10.1074/jbc.271.22.12687. [PubMed: 8663110].

14. Wang S, El-Deiry WS. TRAIL and apoptosis induction by TNFfamily death receptors. Oncogene. 2003;22(53):8628-33. doi: 10.1038/sj.onc.1207232. [PubMed: 14634624].

15. Dimberg LY, Anderson CK, Camidge R, Behbakht K, Thorburn A, Ford HL. On the TRAIL to successful cancer therapy? Predicting and counteracting resistance against TRAIL-based therapeutics. Oncogene. 2013;32(11):1341-50. doi: 10.1038/onc.2012.164. [PubMed: 22580613].

16. Thomas LR, Johnson RL, Reed JC, Thorburn A. The C-terminal tails of tumor necrosis factor-related apoptosis-inducing ligand (TRAIL) and Fas receptors have opposing functions in Fasassociated death domain (FADD) recruitment and can regulate agonist-specific mechanisms of receptor activation. $J$ Biol Chem. 2004;279(50):52479-86. doi: 10.1074/jbc.M409578200. [PubMed: 15452120].

17. Sträter J, Hinz U, Walczak H, Mechtersheimer G, Koretz K, Herfarth C, et al. Expression of TRAIL and TRAIL receptors in colon carcinoma: TRAIL-R1 is an independent prognostic parameter. Clin Cancer Res. 2002;8(12):3734-40. [PubMed: 12473583].
18. Stuckey DW, Shah K. TRAIL on trial: preclinical advances in cancer therapy. Trends Mol Med. 2013;19(11):685-94. doi: 10.1016/j.molmed.2013.08.007. [PubMed: 24076237].

19. Insinga A, Monestiroli S, Ronzoni S, Gelmetti V, Marchesi $F$, Viale A, et al. Inhibitors of histone deacetylases induce tumorselective apoptosis through activation of the death receptor pathway. Nat Med. 2005;11(1):71-6. doi: 10.1038/nm1160. [PubMed: 15619634].

20. Nebbioso A, Clarke N, Voltz E, Germain E, Ambrosino C, Bontempo P, et al. Tumor-selective action of HDAC inhibitors involves TRAIL induction in acute myeloid leukemia cells. Nat Med. 2005;11(1):77-84. doi: 10.1038/nm1161. [PubMed: 15619633].

21. Leonel AJ, Alvarez-Leite JI. Butyrate: implications for intestinal function. Curr Opin Clin Nutr Metab Care. 2012;15(5):474-9. doi: 10.1097/MCO.0b013e32835665fa. [PubMed: 22797568].

22. Paskova L, Smesny Trtkova K, Fialova B, Benedikova A Langova K, Kolar Z. Different effect of sodium butyrate on cancer and normal prostate cells. Toxicol In Vitro. 2013;27(5):1489-95. doi: 10.1016/j.tiv.2013.03.002. [PubMed: 23524101].

23. Jia X, Zheng Y, Guo Y, Chen K. Sodium butyrate, and panobinostat induces apoptosis of chronic myeloid leukemia cells via multiple pathways. Mol Genet Genomic Med. 2019;7(5):e613. doi: 10.1002/mgg3.613. [PubMed: 30891950].

24. Gazzaniga MS, Ivry RB, Mangun GR. Cognitive Neuroscience: The Biology of the Mind: Fourth Edition: WW Norton; 2013.

25. Malekzadeh R, Bishehsari F, Mahdavinia M, Ansari R. Epidemiology and molecular genetics of colorectal cancer in Iran: a review. Arch Iran Med. 2009;12(2):161-9.

26. Gura T. How TRAIL kills cancer cells, but not normal cells. Science 1997;277(5327):768. doi: 10.1126/science.277.5327.768. [PubMed: 9273698].

27. Ferrante RJ, Kubilus JK, Lee J, Ryu H, Beesen A, Zucker B, et al. Histone deacetylase inhibition by sodium butyrate chemotherapy ameliorates the neurodegenerative phenotype in Huntington's disease mice. J Neurosci. 2003;23(28):941827. doi: 10.1523/JNEUROSCI.23-28-09418.2003. [PubMed: 14561870]

28. Xie C, Wu B, Chen B, Shi Q, Guo J, Fan Z, et al. Histone deacetylase inhibitor sodium butyrate suppresses proliferation and promotes apoptosis in osteosarcoma cells by regulation of the MDM2-p53 signaling. OncoTargets Ther. 2016;9:4005-13. doi: 10.2147/OTT.S105418. [PubMed: 27445491].

29. Yamamura T, Matsumoto N, Matsue Y, Okudera M, Nishikawa Y, Abiko Y, et al. Sodium butyrate, a histone deacetylase inhibitor, regulates Lymphangiogenic factors in oral cancer cell line HSC-3. Anticancer Res. 2014;34(4):1701-8. [PubMed: 24692699].

30. Bonnotte B, Favre N, Reveneau S, Micheau O, Droin N, Garrido $\mathrm{C}$, et al. Cancer cell sensitization to fas-mediated apoptosis by sodium butyrate. Cell Death Differ. 1998;5(6):480-7. doi: 10.1038/sj.cdd.4400371. [PubMed: 10200499].

31. Chopin V, Toillon RA, Jouy N, Bourhis XL. Sodium butyrate induces P53-independent, Fas-mediated apoptosis in MCF-7 human breast cancer cells. Br J Pharmacol. 2002;135(1):79-86. doi: 10.1038/sj.bjp.0704456. [PubMed: 11786482].

32. Hernandez A, Thomas R, Smith F, Sandberg J, Kim S, Chung DH, et al. Butyrate sensitizes human colon cancer cells to TRAIL-mediated apoptosis. Surgery. 2001;130(2):265-72. doi: 10.1067/msy.2001.115897. [PubMed: 11490359].

33. Kim YH, Park JW, Lee JY, Kwon TK. Sodium butyrate sensitizes TRAIL-mediated apoptosis by induction of transcription from the DR5 gene promoter through Sp1 sites in colon cancer cells. Carcinogenesis. 2004;25(10):1813-20. doi: 10.1093/carcin/bgh188. [PubMed: 15142888]. 